УДК 14.141

DOI: $10.18101 / 1994-0866-2019-1-3-9$

\title{
ГЛОБАЛИЗАЦИЯ КАК ЗАКОНОМЕРНЫЙ РЕЗУЛЬТАТ ИСТОРИЧЕСКОГО ПРОЦЕССА И ЕЕ СОВРЕМЕННЫЕ ИНТЕРПРЕТАЦИИ
}

\author{
(C) Жамсаев Михаил Батожапович \\ кандидат философских наук, старший преподаватель, \\ Бурятский государственный университет им. Д. Банзарова \\ Россия, 670000, Улан-Удэ, ул. Смолина, 24а \\ E-mail: mzhamsaev@bk.ru \\ (C) Чагдурова Эржена Дондобовна \\ кандидат философских наук, доцент, \\ Бурятский государственный университет им. Д. Банзарова \\ Россия, 670000, г. Улан-Удэ, ул. Смолина, 24а \\ E-mail: chagd60@mail.ru
}

В статье осуществляется социально-философский анализ различных попыток понимания проблемы глобализации. В рамках методологической традиции цивилизационного подхода авторами выделяются три основных направления интерпретации глобализационного процесса: глобализационный скептицизм, трансформизм и гиперглобализм. В каждом из выделенных направлений, в свою очередь, отмечается наличие ряда теорий, каждая из которых вызывает серьезный интерес. В целом представители скептицизма отрицают факт существования глобализации, доказывая, что противостояние между цивилизациями усиливается. Трансформизм приходит к выводу, что происходит распространение западных институтов модернизации, основу которых составляют капитализм и демократия с учетом растущей роли национальных государств, требующих глокализации. Сторонники гиперглобализма говорят о неизбежности единого будущего для всего человечества. Авторы приходят к выводу, что глобализация представляет собой результат объективного исторического процесса, избежать который не представляется возможным.

Ключевые слова: глобализация; философия истории; глобализационный скептицизм; трансформизм; гиперглобализм; глокализация; факторы глобализации.

Для цитирования:

Жамсаев М. Б., Чагдурова Э. Д. Глобализация как закономерный результат исторического процесса и ее современные интерпретации // Вестник Бурятского государственного университета. Философия. 2019. Вып. 1. С. 3-9.

Понятие глобализации родилось в поле социально-гуманитарного знания в 80-е гг. ХХ в., в течение почти полувека активно дискутировались ее основания, проявления и перспективы. Социально-философское исследование данного феномена как исторического процесса требует своего законного места в теории исторического развития человечества. И сегодня можно проследить, как в зависимости от методологии интерпретируются глобализационные процессы.

Наиболее ярко это демонстрирует цивилизационный подход, одним из важнейших положений которого является постулат об изначальной изолированности отдельных сообществ людей [1]. Благодаря этому существует, как утверждается, уникальность исторического пути развития для каждой цивилизации. При этом изолированность сохраняется в дальнейшем развитии отдельных сообществ и 
является чем-то постоянным, самовоспроизводимым, сохраняющимся вне зависимости от воли человека или некоторых социальных процессов.

Цивилизационный подход утверждает, что не существует глобальных общечеловеческих законов исторического развития и история отдельной цивилизации уникальна точно так же, как жизнь отдельных коллективов и судьба конкретного человека. Для каждой цивилизации всегда действуют объективно неповторимые исторические условия, которые эту самую уникальность определяют.

Существующие на сегодняшний день учения о культуре во многом являются производными цивилизационного подхода. Культуры отдельных сообществ формируют самобытность цивилизации, частью которой они являются, зачастую оставаясь последним бастионом перед ее исчезновением и становясь духовным наследием после ее гибели. Исследование культуры как невероятно сложного феномена представляет серьезную проблему, и не случайно до сих пор не дано однозначного ее определения.

Культурологические поиски отталкиваются чаще всего от теоретического обоснования общества, как это происходит в цивилизационном и других методологических подходах исследования культуры. «Они предлагают разные ориентиры и дают наводки в области эмпирического знания, выстраивают модели и схемы, которые могли бы помочь в выделении особенностей культуры, ее содержания и функций. Однако основная задача теории заключается не в том, чтобы накопить энное количество гипотез и предложений, а прежде всего в том, чтобы научиться выделять культуру как эмпирически заданный объект наблюдений, т. е. научиться точно и скрупулезно исследовать ее состояния, выявлять степень ее влияния на экономические успехи и исторические события», - пишут А. Оганов и И. Хангельдиева в своем труде «Теория культуры» [2].

Как бы то ни было, именно исследование культуры невероятно усложняет представление об обществе прежде всего из-за вариативности изучаемого феномена, разнообразия народов и этносов, уровней внутри культуры отдельных наций, разнообразием наблюдаемых и приписываемых ей функций и т. д.

Вызывает интерес семиотическая концепция культуры как социокода М. К. Петрова [3]. Автор проводит аналогию социального и биологического, которая в итоге отделила социально-историческое от эволюционно-биологического. Культуре в этом случае отводится роль некоего «генома», который дает обществу доступные ему степени свободы в его развитии. Петров утверждает, что от богатства и разнообразия культуры зависят не только перспективы, но и болезни общества. Образы духовного бытия, понятия и готовые сценарии поведения все это и многое другое предопределяет не только общее направление деятельности отдельных личностей, но и саморазвитие общества в долгосрочной перспективе примерно так же, как геном живого существа определяет форму и развитие его тела. Этот социокод способен крайне устойчиво сохранять свою самобытность, но при этом он пластичен и способен к развитию. Понятие социокода коррелирует с теориями Н. Я. Данилевского, О. Шпенглера и А. Дж. Тойнби в той части, где авторами осуществляется поиск формально-знакового ядра культуры.

Цивилизационный подход налагает свой отпечаток на интерпретацию глобализационного процесса, что проявляется в теориях «реальной регионализации» или «глобализационного скептицизма», представленных такими учеными, как П. Хирст, Г. Томпсон, И. Валлерстайн и др. [4]. 
М. Б. Жамсаев, Э. Д. Чагдурова. Глобализация как закономерный результат исторического процесса и ее современные интерпретации

Наиболее значимыми и известными в этом отношении являются работы С. Хантингтона, особенно его труд «Столкновение цивилизаций». В этой работе утверждается, что современный мир разделен на цивилизационные блоки, конфликт между которыми неизбежен в силу принципиальных различий. Как защитная реакция на процессы глобализации в мире заметно усиливаются национализм, культурный и идеологический фундаментализм, что ведет к выводам об утопичности идей мирового правительства в традиционной для государства форме и функциях. Хантингтон признает недостаточно эффективными методы доминирования одних цивилизаций над другими с помощью глобальной экономики, глобальной культуры и других социальных и политических проектов. Хотя, по его мнению, остается возможность точечного, даже дозированного воздействия на различные регионы мира, это не спасает от неизбежного силового разрешения большинства межцивилизационных конфликтов, смягчить которые будет крайне трудно. Только путем комплексного воздействия возможно будет както уменьшить последствия подобных кризисов [5].

Одной из наиболее заметных работ, развивающих эту мысль, является книга Б. Барбера, название которой само по себе уже звучит как емкая характеристика современных международных и межкультурных отношений - «Джихад против Мак-мира» [6].

В целом «скептики» отрицают факт существования глобализации, доказывают, что экономической интеграции в мире нет, как не уменьшаются различия между Севером и Югом. Напротив, утверждают эти авторы, противостояние между сильными регионами становится более активным, мир сегодня еще менее взаимозависим, чем сотню лет назад.

Другая группа авторов сводят процесс глобализации к очередному этапу развития общества - например, к модернизации. Здесь глобализация рассматривается как перманентный процесс, осуществляющийся посредством проведения реформ и инноваций, что сегодня означает переход к постиндустриальному обществу. Позднее все больше упоминается термин «вестернизация», т. е. распространение западных институтов модернизации, основу которых составляют капитализм и демократия. Эта теория является производной цивилизационной методологии и может быть обозначена как трансформизм.

В условиях глобальной экономики национальное государство перестает быть основным системообразующим элементом мировой политики и экономики, и деление на победителей и проигравших следует заменить на деление по социальным группам и классам. В выигрыше окажется транснациональный класс менеджеров, специалистов по финансам и информационным технологиям и т. д.

Национальная экономика, национальная культура размываются глобальными потоками товаров, людей, капиталов и информации, что усиливает роль институтов глобального управления. Постоянное взаимодействие людей посредством глобальной коммуникационной инфраструктуры приводит к повышению осознания общих интересов и проблем, что, в свою очередь, ведет к формированию глобального гражданского общества и глобального сознания, о чем пишет ряд зарубежных и отечественных исследователей [7].

В то же время ярко проявляются и противоположные тенденции, о которых впервые заговорили в маркетинге, используя термины «глокальный» и «глокализация» применительно к адаптации какой-либо фермерской технологии к местным условиям, адаптации глобального товара под каждый конкретный рынок [8, 
c. 33]. За этим стояло вполне ясное осознание того, что локальное и разнообразное продается лучше. В социальные науки термин «глокализация» вошел, получил распространение и осмысление благодаря одному из ключевых теоретиков глобализации - Р. Робертсону [9].

Сегодня идеи концепции глокализации гармонично присутствуют в работах практически всех исследователей, относящихся к сторонникам теории трансформизма. Термин «глокализация» характеризует двухуровневость глобализации, одновременность процессов глобализации и локализации. Теория глокализации во многом основывается на более широкой теории гибридизации, разработанной в середине XX в., призванной охарактеризовать культурные феномены колониального и постколониального мира, демонстрирующего формирование и существование культурных форм, основанных на синтезе двух и более культур [8, c. 34].

Другой ключевой идеей трансформистов является констатация растущей роли национального государства. Отстаивающие ее авторы утверждают, что под действием глобализационных процессов «срабатывают» определенные механизмы самозащиты, которые вызывают интенсификацию и возрождение национальной идентичности $[8$, с. 15]. Государства вынуждены разрабатывать стратегии поведения в условиях глобализации, реагировать на вызовы глобализации, что еще больше усиливает их роль, подчеркивают П. Бергер, У. Шуеркенс [10]. В этих условиях происходит трансформация сути классического государства, которая заключается в изменении характера связей между суверенностью, территориальностью и государственной властью. Такая трансформация государства полностью соответствует логике детерриторизации и глокализации, а также унификации и стимулирования развития разнообразия [8, с. 34].

Но цивилизационный подход также дает и другую возможность интерпретации глобализации, допуская полное разрушение некоторых и, в конце концов, всех традиционных культур под влиянием все новых и новых факторов глобализации. Тут он часто исходит из идеи неравномерности процесса глобализации, когда ее интенсивность в разные исторические периоды то замедляется, то приобретает стремительность. Это направление, которое следует логике неолиберализма и приветствует триумф индивидуальности и рыночных механизмов над властью и гегемонией государства, можно назвать гиперглобализмом [11]. Сторонники данного направления обращают большее внимание на экономическую интеграцию и формирование единого информационного пространства.

В поздний советский и постсоветский периоды в российском обществе сложилось весьма определенное мнение о роли и значении Америки и Западной Европы в ее судьбе. На протяжении практически всей своей истории Россия была вынуждена опасаться агрессивной внешней политики Запада. Природа этих опасений должна быть ясна из самой сути глобализации, которая носит отнюдь не мирный и даже для некоторых регионов весьма катастрофический характер. По мнению ряда российских ученых [12], современные мировые экономические, политические, информационные, социокультурные отношения асимметричны и неравномерны, что очень опасно для мира в целом и, в частности, представляет угрозу для России.

Ясно, что нашей стране в новых условиях необходимо найти свое место в глобальном мире, используя сильные стороны национального интеллектуального и ресурсного капитала, выработать верный политический курс, позволяющий 
М. Б. Жамсаев, Э. Д. Чагдурова. Глобализация как закономерный результат исторического процесса и ее современные интерпретации

успешно развиваться в социально-экономическом плане. И здесь немаловажную роль будет играть то идеологическое поле, в рамках которого будут осуществляться преобразования. Главной задачей сторонников глобализации становится утверждение, что глобализация должна стать более гуманной, учитывающей интересы всего человечества [13].

Пытаясь рассматривать глобализацию как исторический процесс, нельзя ограничиваться периодом современности. Конечно, глобализационные процессы наиболее ярко проявились в новейший период истории, что связано с научнотехническим развитием человечества, значительно интенсифицировавшим все сферы жизни общества. На протяжении XX в. мы видим, что именно технический прогресс порождает факторы глобализационного процесса. Сначала индустриальная революция, которая спровоцировала мировые войны, затем принятие на вооружение наиболее могущественными странами мира ядерного оружия, которое благодаря количеству и качеству быстро приобрело глобальное значение, следом мы отмечаем развитие информационных технологий. Иначе говоря, мы можем выделить множество факторов, которые подталкивают человечество ко все большему углублению глобализационных процессов именно в современном мире.

Вместе с тем глобализационные факторы исторического развития мы можем увидеть и в глубоком прошлом, где они также являются неотъемлемой частью исторического процесса. Однажды возникнув, они по-прежнему оказывают влияние на дальнейшее развитие человечества. К этим факторам причисляют ряд кардинальных переворотов как в образе жизни, так и в мышлении, и в технологии: неолитическая, административная, транспортная, промышленная, научнотехническая (индустриализация) и информационная революции. Современное общество в этом контексте приобретает все больше подобных черт и свойств.

В последнее время часто звучат идеи «конца глобализации». Здесь, наряду с рассуждениями об усталости человечества от бесконечных перемен, о неприятии унификации культур, о вспыхнувшем в ответ нациоренессансе, говорится о прямом противодействии процессу глобализации со стороны ведущих государств мира. Более того, проводится мысль, что это противодействие может остановить процессы глобализации, поскольку затрагивает основы экономического благополучия всех стран мира.

Несомненно, что глобализация отнюдь не является безобидным процессом, она несет множество проблем и бедствий человечеству, как и многие другие исторические изменения. Но наше мнение склоняется к тому, что этот феномен является результатом объективного хода истории, процессом, избежать которого невозможно. «Исторически это проявление общих тенденций самоорганизации, роста разнообразия и сложности организации общества, относительно безразличное к формационной структуре» [14, с. 42]. Переживаемый миром экономический кризис затронул многие стороны жизни, заставил вернуться к идее национальных государств с замкнутой экономикой, но информационную и культурную глобализацию уже не остановить.

\section{Литература}

1. Данилевский Н. Я. Россия и Европа. М.: Книга, 1991. 573 с.; Шпенглер О. Закат Европы. Ростов н/Д.: Феникс, 1998. 637 с.; Тойнби А. Дж. Постижение истории. М.: Прогресс. Культура, 1996. 607 с. 
2. Оганов А., Хангельдиева И. Теория культуры. М.: Лань, 2016. 560 с. С. 58.

3. Петров М. К. Язык, знак, культура. М.: Едиториал УРСС, 2004. 328 с.

4. Hirst P., Thompson G. Globalization in Question: The International Economy and the Possibilities of Governance. Cambridge: Polity Press, 1996; Валлерстайн И. Исторический капитализм. Капиталистическая цивилизация. М.: Товарищество научных изданий КМК, 2008. $176 \mathrm{c}$.

5. Хантингтон С. Столкновение цивилизаций. М.: АСТ, АСТ Москва, 2006. 571 с.

6. Barber B. R. Jihad Vs. McWorld // The Atlantic Monthly. 1992. March. Vol. 269, No. 3. Р. 53-65.

7. Булл Х. Теория международных отношений: пример классического подхода // Теория международных отношений: хрестоматия. М.: Гардарики, 2002. С. 187-200; Пешков М. Глобализация: сущность, нынешняя фаза, перспективы. Pro et Contra. 1999. Т. 4, № 4. 122 с.; Мантатов В. Глобализация, устойчивое развитие и общество будущего // Век глобализации. 2009. № 1. С. 175-184; и др.

8. Никифоров А. А. Идеи теории глобализации и взгляды ее представителей в области экономики и управления // Научный журнал НИУ ИТМО. Серия Экономика и экономический менеджмент. 2015. № 3. С. 28-34.

9. Featherstone M., Lash S., Robertson R. Global Modernities. SAGE, 1995-01-01. 306 c.

10. Berger P. Four Faces of Global Culture // National Interest. 1997. Vol. 49. Р. 23-29; и др.

11. Коуэн Т. Среднего более не дано: Как выйти из эпохи Великой стагнации. М.: Изд-во Института Гайдара, 2015. 320 с.

12. Иноземцев В. Л. Неизбежность многополюсной цивилизации. Мегатренды мирового развития. М., 2001. 237 с.; и др.

13. Джагдиш Бхагвати. В защиту глобализации. М.: Ладомир, 2005. 451 с.

14. Рандалова О. Ю. К проблеме изучения современного глобального развития. Вестник Бурятского государственного университета. Серия Философия. 2012. Вып. 6. C. $41-43$.

\section{GLOBALIZATION AS AN EXPECTED RESULT OF THE HISTORICAL PROCESS AND ITS MODERN INTERPRETATIONS}

Mikhail B. Zhamsaev

Cand. Sci. (Philos.), Senior Lecturer,

Dorzhi Banzarov Buryat State University

24a Smolina St., Ulan-Ude 670000, Russia

E-mail: mzhamsaev@bk.ru

Erzhena D. Chagdurova

Cand. Sci. (Philos.), A/Prof.,

Dorzhi Banzarov Buryat State University,

24a Smolina St., Ulan-Ude 670000, Russia

E-mail: chagd60@mail.ru

The article presents a socio-philosophical analysis of different efforts to understand the problem of globalization. Within the framework of the methodological tradition of civilization approach, we have singled out three main trends in interpretation of the globalization process: globalization skepticism, transformism and hyperglobalism. Each of these trends, in turn, include a number of theories of special interest. In general, representatives of skepticism deny the existence of globalization, they argue that the confrontation between civilizations is increasing. Proponents of transformism consider that there is a proliferation of Western modernization institutions based on capitalism and democracy, and the role of nation-states that require glocalization is growing. Supporters of hyperglobal- 
М. Б. Жамсаев, Э. Д. Чагдурова. Глобализация как закономерный результат исторического процесса и ее современные интерпретации

ism claim the inevitability of a common future for all mankind. We conclude that globalization is the result of an objective historical process that cannot be avoided.

Keywords: globalization; philosophy of history; globalization skepticism; transformism; hyperglobalism; glocalization; globalization factors. 